\title{
PENYUSUNAN ALAT UKUR CHARACTER STRENGTH BAHASA INDONESIA
}

\author{
Garvin \\ Universitas Bunda Mulia \\ garvin.goei@gmail.com
}

\begin{abstract}
Character strength is one of the main topics of positive psychology that is beneficial for of individuals' well-being, both in clinical, educational, or industrial-organizational settings. Character strength is a concept that highlights the universal positive qualities of human. Unfortunately, it is still difficult to find a measurement scale of character strength in Indonesia that can be used in researc. Although free character strength assessments are available on the internet, there is no scale that can be used by researchers. This research is intended to construct a character strength measurement scale that can be used for research in Indonesia. This study involved 101 students (79.2\% are female) to fill the character strength scale that has been constructed by researcher using Peterson \& Seligman's concept. The reliability test shows that this scale is quite reliable, with a Cronbach's Alpha score ranged between $\alpha=$ 0.520 - 0.858. The results of the item analysis indicate that there are some items which are not appropriate in measuring certain domains on a scale, so researcher discards these items. The scale which originally consisted of 144 items, but after going through the testing and disposal process, left 120 items that could be used. This study concludes that the scale can be used for character strengths research in Indonesia.
\end{abstract}

Keywords: character strengths, positive psychology, scale construction

\begin{abstract}
ABSTRAK
Kekuatan karakter atau character strengths adalah salah satu pembahasan utama psikologi positif yang bermanfaat bagi kesejahteraan individu, baik dalam konteks klinis, pendidikan, maupun industri-organisasi. Kekuatan karakter adalah sebuah konsep yang menyorot kualitaskualitas positif manusia yang universal dalam berbagai budaya. Sayangnya, masih sulit ditemukan alat ukur kekuatan karakter dalam Bahasa Indonesia yang dapat digunakan dalam penelitian di Indonesia. Meski sudah tersedia pemeriksaan kekuatan karakter gratis di internet, namun tidak tersedia skala yang dapat digunakan oleh peneliti. Penelitian ini bermaksud untuk membuat alat ukur atau skala kekuatan karakter yang dapat digunakan untuk penelitian di Indonesia. Penelitian ini melibatkan 101 mahasiswa (79,2\% adalah perempuan) untuk mengisi skala kekuatan karakter yang peneliti susun berdasarkan konsep Peterson \& Seligman. Hasil uji reliabilitas menunjukkan bahwa skala ini tergolong reliabel, dengan rentang reliabilitas antara $\alpha=0,520-0,858$. Hasil analisis butir menunjukkan terdapat beberapa butir yang kurang tepat dalam mengukur ranah-ranah tertentu dalam skala, sehingga peneliti membuang butirbutir tersebut. Skala yang semula terdiri dari 144 butir, setelah melalui proses pengujian dan pembuangan butir, menyisakan 120 butir yang dapat digunakan. Penelitian ini menyimpulkan bahwa skala dapat digunakan dalam penelitian kekuatan karakter di Indonesia.
\end{abstract}

Kata Kunci: kekuatan karakter, penyusunan skala, psikologi positif 


\section{PENDAHULUAN}

Setelah positive psychology movement atau gerakan psikologi positif diinisiasi oleh presiden American Psychological Association, Martin Seligman, pada tahun 1990 silam; penelitian-penelitian psikologi mulai bergerak menjadi tidak hanya berfokus pada gangguan kejiwaan dan penangangannya, melainkan juga berfokus pada kualitas positif manusia yang sehat secara mental dan cara mengembangkannya. Psikologi positif merupakan salah satu pendekatan dalam psikologi yang berusaha untuk memelajari dan mendalami sisi-sisi positif manusia. Psikologi positif bermula dari Seligman yang kala itu mengkritisi psikologi yang hanya melakukan studi-studi mengenai gangguan psikologis, sehingga psikologi dikenal menjadi ilmu tentang gangguan dan permasalahan psikologis saja. Padahal, psikologi juga dapat digunakan untuk memelajari manusia-manusia yang sehat secara mental dan bagaimana meningkatkan kualitas-kualitas baik pada manusia. Menurut Seligman (2002), psikologi seharusnya tidak membuat manusia yang sakit menjadi tidak sakit saja, tetapi psikologi juga bisa dilakukan untuk membuat manusia yang sehat secara mental menjadi lebih baik, seperti yang disampaikan oleh Peterson (2006) bahwa psikologi positif merupakan studi ilmiah tentang apa yang membuat hidup paling berharga. Dengan demikian, psikologi bisa berkontribusi lebih banyak kepada manusia dan dapat diterapkan ke dalam berbagai aspek kehidupan.

Maka, sejak Martin Seligman mencetuskan gerakan psikologi positif ini, psikologi menjadi lebih berkembang menjadi ilmu yang juga memelajari orang sehat. Berbagai upaya dilakukan untuk memelajari kualitas-kualitas positif pada manusia, mulai dari character strength (Peterson \& Seligman, 2004), psychological well-being atau kesejahteraan psikologis, subjective well-being atau kesejahteraan subjektif, engagement, grit atau ketabahan (Duckworth, 2016), resiliensi, growth mindset, dan self-compassion (Neff, 2011). Berbagai asosiasi psikologi positif pun berdiri di berbagai negara, menandakan bahwa gerakan psikologi 
positif ini sangat diterima oleh masyarakat dunia. Di Indonesia sendiri, mata kuliah psikologi positif sudah masuk ke dalam kurikulum Program Studi S1 Psikologi di berbagai universitas.

Salah satu topik yang penting dalam psikologi positif adalah character strength atau kekuatan karakter. Character strengths dirumuskan dengan tujuan untuk membentuk hidup yang baik (the good life) pada diri seseorang maupun orang lain (Peterson \& Seligman, 2004). Park dan Peterson (2009) menyampaikan bahwa character strengths merupakan aspek-aspek kepribadian yang dihargai secara moral, dan merupakan fondasi dari pengembangan diri seumur hidup yang optimal. Penelitian yang dilakukan Wagner, Gander, Proyer, \& Ruch (2019) menemukan bahwa character strengths berhubungan secara positif dengan lima indikator kebahagiaan, yakni (1) afeksi positif, (2) engagement, (3) hubungan yang berkualitas, (4) kebermaknaan, dan (5) pencapaian. Character strengths tidak hanya berkontribusi terhadap kesejahteraan seseorang secara hedonic saja, tetapi juga secara eudaimonic (Harzer, 2016). Character strengths juga dapat memprediksi tingkat resiliensi seseorang (Martinez-Marti \& Ruch, 2016). Lebih lanjut lagi, penggunaan character strengths yang sesuai dapat meningkatkan kepuasan hidup seseorang (Douglass \& Duffy, 2015). Penelitian-penelitian tersebut menunjukkan bahwa character strengths memiliki hubungan yang erat dengan kesejahteraan individu, yang merupakan salah satu dari tujuan berdirinya psikologi positif.

Character strengths juga dapat diaplikasikan di dalam tempat kerja. Misalnya, Heintz dan Ruch (2019) menemukan bahwa character strengths berhubungan dengan kepuasan bekerja pada seseorang. Penggunaan strength dalam pekerjaan juga diketahui secara positif dengan produktivitas, organizational citizenship behavior, dan kepuasan kerja (Lavy \& Littman-Ovadia, 2017). Character strength juga bisa digunakan sebagai alat bantu dalam pemilihan profesi tertentu. Misalnya, penelitian yang dilakukan oleh Huber et al. (2019) menemukan bahwa dokter di rumah sakit memiliki lima character strengths utama, yakni: (1) fairness / keadilan, (2) honesty / kejujuran, (3) judgment / kemampuan melakukan penilaian, 
(4) kindness / kebaikan hati, dan (5) love / cinta. Kelima karakter itu akan membuat seorang dokter lebih sejahtera dan engaged dalam bekerja. Riset yang dilakukan oleh Bakker, Hetland, Olsen, dan Espevik (2018) menemukan bahwa mengaplikasikan character strengths diketahui dapat meningkatkan kesejahteraan karyawan.

Berdasarkan paparan-paparan di atas, diketahui bahwa character strengths merupakan konstruk yang penting di dalam psikologi, terutama psikologi positif. Baik individu maupun organisasi bisa mendapatkan manfaat jika individu mampu memanfaatkan character strength sebaik mungkin. Character strengths, layaknya kepribadian, cenderung stabil sepanjang waktu (Gander, Hofmann, Proyer, \& Ruch; 2019). Character strengths seseorang dapat berubah jika terjadi peristiwa yang signifikan dalam hidup individu. Character strengths sendiri memang diketahui berhubungan dengan model kepribadian big five (Peterson \& Seligman, 2004), seperti misalnya zest, humor, dan playfulness berhubungan dengan extroversion; sedangkan curiosity, creativity, dan love of learning berhubungan dengan openness to experience. Hanya aspek neuroticism saja yang tidak berhubungan dengan character strengths. Seligman sendiri menyatakan bahwa character strengths merupakan sebuah teori kepribadian.

Meski manfaat serta pentingnya character strengths sudah banyak diteliti di luar, namun di Indonesia konsep ini masih jarang diteliti. Penulis mencoba untuk menelurusi penelitian-penelitian character strengths dan hanya menemukan sedikit. Misalnya, Maryama (2015) menemukan bahwa character strengths berpengaruh terhadap stres akademik pada pelajar di Indonesia, terutama character strengths jenis bravery dan persistence. Atau penelitian Multahada (2016) yang menemukan bahwa character strengths berpengaruh terhadap resiliensi pada perawat.

Kurang banyaknya penelitian mengenai character strengths bisa jadi dikarenakan oleh kurangnya alat ukur character strengths yang valid dan reliabel. Dalam kedua penelitian character strengths di Indonesia yang dipaparkan di atas, alat ukur yang digunakan adalah VIA 
Inventory of Strengths - disingkat VIA-IS - yang dibuat pada tahun 2004 (Peterson \& Seligman, 2004). Sebenarnya alat ukur ini sudah tersedia dalam Bahasa Indonesia dan orang-orang dapat memanfaatkan free assessment dalam Bahasa Indonesia melalui situs VIA Institute of Character (www.viacharacter.org). Sayangnya, VIA-IS hanya sebatas bisa digunakan sebagai testee, sedangkan peneliti menemukan bahwa akses untuk menggunakan alat ukur VIA-IS dalam penelitian. Padahal, ketersediaan alat ukur yang dapat diakses oleh peneliti untuk digunakan di dalam penelitian akan sangat membantu meningkatkan penelitian-penelitian character strengths di Indonesia.

Dengan hadirnya alat ukur character strengths versi Indonesia, maka peneliti-peneliti psikologi positif dapat menggunakan alat ukur tersebut untuk meneliti character strengths. Lebih lanjut lagi, dengan terbukanya kesempatan untuk meneliti character strengths, maka kesempatan untuk penelitian psikologi positif dan well-being menjadi terbuka semakin lebar.

Penelitian ini bersifat deskriptif untuk menggambarkan reliabilitas skala serta hasil analisis butir pada alat ukur character strength. Partisipan penelitian ini adalah mahasiswa yang berada pada Program Studi Psikologi Universitas X di Jakarta, dengan rentang usia dimulai dari 17 tahun hingga 26 tahun. Adapun total partisipan dalam penelitian ini adalah 101 orang, dengan $79,2 \%$ dari partisipan adalah perempuan, yakni sebanyak 80 orang. Setelah itu, data yang sudah terkumpul dianalisa oleh peneliti secara deskriptif dengan menggunakan program SPSS.

\section{HASIL PENELITIAN}

Rancangan alat ukur sebanyak 144 butir peneliti susun berdasarkan ke-24 jenis character strengths yang dirumuskan oleh Peterson \& Seligman (2004). Peneliti melakukan uji reliabilitas dan analisa butir pada masing-masing ranah pengukuran character strength. Ranah pertama adalah kreativitas atau creativity. Awalnya hasil uji reliabilitas terhadap 6 butir yang mengukur ranah kreativitas menunjukkan skor $\alpha=0,728$ yang menandakan pengukuran 
sudah reliabel. Namun, terdapat satu butir yang menunjukkan skor korelasi butir total yang berada di bawah 0,3; yakni butir nomor 121 yang menunjukkan skor $r_{i t}=0,093$. Butir nomor 121 kemudian dibuang, dan dengan demikian skor Cronbach's Alpha pun meningkat menjadi $\alpha=0,779$. Hasil lebih mendetail bisa dilihat pada tabel 1 .

Tabel 1. Hasil Uji Reliabilitas dan Analisis Butir Ranah Kreativitas.

\begin{tabular}{lcccc}
\hline \multirow{2}{*}{ No. Butir } & \multicolumn{2}{c}{ Hasil Awal } & \multicolumn{2}{c}{ Hasil Akhir } \\
\cline { 2 - 5 } & $\mathrm{r}_{\text {it }}$ & $\alpha$ & $\mathrm{r}_{\text {it }}$ & $\alpha$ \\
\hline Butir 1 & 0,432 & 0,728 & 0,412 & 0,779 \\
Butir 25 & 0,522 & & 0,570 & \\
Butir 49 & 0,612 & & 0,604 & \\
Butir 73 & 0,529 & & 0,559 & \\
Butir 97 & 0,596 & & 0,622 & (butir dibuang) \\
Butir 121 & 0,093 & & \multicolumn{2}{c}{} \\
\hline
\end{tabular}

Berdasarkan hasil pengujian tersebut, peneliti menyimpulkan bahwa pengukuran character strength pada ranah kreativitas tergolong reliabel dan kelima butir tergolong baik. Selanjutnya peneliti menganalisis butir dan menguji reliabilitas pada ranah kedua, yakni keingintahuan atau curiosity. Enam butir yang digunakan untuk mengukur ranah keingintahuan diuji dan menunjukkan skor $\alpha=0,821$ dengan $r_{i t}=0,509-0,683$. Dengan demikian, tidak ada butit yang dibuang. Detail hasil pengujian tersaji dalam tabel 2.

Tabel 2. Hasil Uji Reliabilitas dan Analisis Butir Ranah Keingintahuan.

\begin{tabular}{lcc}
\hline \multicolumn{1}{c}{ No. Butir } & \multicolumn{2}{c}{ Nilai } \\
\cline { 2 - 3 } & $\mathrm{r}_{\text {it }}$ & $\alpha$ \\
\hline Butir 2 & 0,514 & 0,821 \\
Butir 26 & 0,590 & \\
Butir 50 & 0,625 & \\
Butir 74 & 0,683 & \\
Butir 98 & 0,509 & \\
Butir 122 & 0,615 & \\
\hline
\end{tabular}

Pengukuran pada ranah keingintahuan pun dianggap reliabel dengan butir-butir yang dapat mengukur keingintahuan dengan baik. Ranah berikutnya yang akan diuji adalah judgment atau penilaian. Mulanya hasil uji reliabilitas menunjukkan skor Cronbach's Alpha 
yang sangat tidak memuaskan, yakni $\alpha=0.290$ dengan $r_{\text {it }}$ berkisar antara $-0,080$ hingga 0,320 . Hasil yang tidak memuaskan. Namun setelah dua butir dengan skor $r_{i t}$ terendah, yakni butir nomor 99 dan nomor 123 dibuang, maka terjadi peningkatan reliabilitas yang signfikan, yakni menjadi $\alpha=0,592$. Detail tertuang dalam tabel 3 .

Tabel 3. Hasil Uji reliabilitas dan Analisis Butir Ranah Penilaian

\begin{tabular}{lcccc}
\hline \multirow{2}{*}{ No. Butir } & \multicolumn{2}{c}{ Hasil Awal } & \multicolumn{2}{c}{ Hasil Akhir } \\
\cline { 2 - 5 } & $\mathrm{r}_{\text {it }}$ & $\alpha$ & $\mathrm{r}_{\text {it }}$ & $\alpha$ \\
\hline Butir 3 & 0,320 & 0,290 & 0,532 & 0,592 \\
Butir 27 & 0,313 & & 0,409 & \\
Butir 51 & 0,081 & & 0,249 & \\
Butir 75 & 0,225 & & 0,338 & \\
Butir 99 & $-0,080$ & & \multicolumn{2}{c}{ (butir dibuang) } \\
Butir 123 & 0,064 & & (butir dibuang) \\
\hline
\end{tabular}

Berdasarkan hasil pengujian-pengujian tersebut, peneliti menyimpulkan bahwa pengukuran pada ranah penilaian tergolong reliabel dan butir-butirnya masih bisa digunakan untuk merepresentasikan indikator character strength ranah penilaian.

Selanjutnya adalah ranah love of learning atau kecintaan terhadap belajar. Pernyataan sebanyak 6 butir diuji reliabilitas dan daya diskriminasi butir. Hasil uji reliabilitas menunjukkan bahwa pengukuarn ranah kecintaan terhadap belajar dalam skala ini tergolong reliabel, dengan $\alpha=0,745$. Ada satu butir yang harus dibuang, yakni butir nomor 100 yang memiliki skor $r_{i t}=0,253$ (di bawah 0,03). Detail daya diskriminasi masing-masing butir tercantum pada tabel 4 .

Tabel 4. Hasil Uji reliabilitas dan Analisis Butir Kecintaan terhadap Belajar

\begin{tabular}{lcccc}
\hline \multirow{2}{*}{ No. Butir } & \multicolumn{2}{c}{ Hasil Awal } & \multicolumn{2}{c}{ Hasil Akhir } \\
\cline { 2 - 5 } & $\mathrm{r}_{\text {it }}$ & $\alpha$ & $\mathrm{r}_{\text {it }}$ & $\alpha$ \\
\hline Butir 4 & 0,727 & 0,745 & 0,755 & 0,776 \\
Butir 28 & 0,537 & & 0,511 & \\
Butir 52 & 0,475 & & 0,509 & \\
Butir 76 & 0,481 & & \multicolumn{2}{c}{0,526} \\
Butir 100 & 0,253 & \multicolumn{3}{c}{ (butir dibuang) } \\
Butir 124 & 0,500 & \multicolumn{2}{c}{0,476} \\
\hline
\end{tabular}


Hasil dari pengujian tersebut menunjukkan bahwa pengukuran character strength pada ranah ini tergolong reliabel dengan butir-butir yang baik.

Ranah kelima yang selanjutnya diuji adalah ranah perspektif. Peneliti menguji 6 butir yang sudah disusun untuk mengukur perspektif. Hasil uji reliabilitas semula menunjukkan angka $\alpha=0,491$; namun setelah dua butir dibuang, reliabilitasnya meningkat menjadi $\alpha=$ 0,520. Hasil pengujian tersaji dalam tabel 5 .

Tabel 5. Hasil Uji reliabilitas dan Analisis Butir Ranah Perspektif

\begin{tabular}{|c|c|c|c|c|}
\hline \multirow[t]{2}{*}{ No. Butir } & \multicolumn{2}{|c|}{ Hasil Awal } & \multicolumn{2}{|c|}{ Hasil Akhir } \\
\hline & $r_{i t}$ & $\alpha$ & $\mathrm{r}_{\mathrm{it}}$ & $\alpha$ \\
\hline Butir 5 & 0,266 & 0,491 & 0,215 & 0,520 \\
\hline Butir 29 & 0,060 & & \multicolumn{2}{|c|}{ (butir dibuang) } \\
\hline Butir 53 & 0,305 & & \multicolumn{2}{|l|}{0,328} \\
\hline Butir 77 & 0,503 & & \multicolumn{2}{|l|}{0,523} \\
\hline Butir 101 & 0,295 & & \multirow{2}{*}{\multicolumn{2}{|c|}{$\begin{array}{l}0,228 \\
\quad \text { (butir dibuang) }\end{array}$}} \\
\hline Butir 125 & 0,138 & & & \\
\hline
\end{tabular}

Meski terdapat dua butir yang masih memiliki nilai $\mathrm{r}_{\mathrm{it}}$ di bawah 0,03 ; yakni butir nomor 5 dan nomor 101, namun peneliti masih mempertahankan kedua butir tersebut karena kalimat pernyataan dalam butir tersebut masih dapat menggambarkan ranah perspektif dengan baik, sesuai dengan konsep dari konstruk. Dengan demikian, pengukuran pada ranah perspektif dianggap cukup reliabel dengan butir-butir yang cukup baik.

Ranah selanjutnya yang akan diuji adalah ranah keberanian atau bravery. Peneliti menguji reliabilitas dari keenam butir yang sudah peneliti tulis dan menunjukkan skor $\alpha=$ 0,594. Setelah ada satu butir pernyataan yang dibuang karena daya diskriminasi yang kurang baik $\left(\mathrm{r}_{\mathrm{it}}<0,03\right)$, maka skor Cronbach's Alpha meningkat menjadi $\alpha=0,637$ dengan rentang skor $r_{i t}$ berkisar antara 0,372 hingga 0,573. Detail terlampir pada tabel 6 . 
Tabel 6. Hasil Uji reliabilitas dan Analisis Butir Ranah Keberanian

\begin{tabular}{lcccc}
\hline \multirow{2}{*}{ No. Butir } & \multicolumn{2}{c}{ Hasil Awal } & \multicolumn{2}{c}{ Hasil Akhir } \\
\cline { 2 - 5 } & $\mathrm{r}_{\text {it }}$ & $\alpha$ & $\mathrm{r}_{\text {it }}$ & $\alpha$ \\
\hline Butir 6 & 0,419 & 0,594 & 0,372 & 0,637 \\
Butir 30 & 0,099 & & \multicolumn{2}{c}{ (butir dibuang) } \\
Butir 54 & 0,228 & & 0,286 \\
Butir 78 & 0,535 & & 0,573 & \\
Butir 102 & 0,370 & & 0,377 & \\
Butir 126 & 0,381 & & 0,384 & \\
\hline
\end{tabular}

Berdasarkan data di atas, peneliti menyimpulkan bahwa pengukuran character strength pada ranah keberanian tergolong reliabel dengan butir-butir yang memiliki daya diskriminasi yang baik.

Ranah ketujuh dalam character strength yang diuji adalah ketekunan atau perseverance. Hasil uji reliabilitas menunjukkan skor Cronbach's Alpha sebesar $\alpha=0,732$ dengan rentang skor $r_{i t}=0,381-0,601$. Dengan demikian, keenam butir yang digunakan untuk mengukur ranah ketekunan tetap dipertahankan atau tidak ada yang dibuang. Tabel 7 mendeskripsikan hasil pengukuran dengan lebih mendetail.

Tabel 7. Hasil Uji reliabilitas dan Analisis Butir Ranah Ketekunan

\begin{tabular}{lcc}
\hline No. Butir & \multicolumn{2}{c}{ Hasil Pengujian } \\
\cline { 2 - 3 } & $\mathrm{r}_{\text {it }}$ & $\alpha$ \\
\hline Butir 7 & 0,415 & 0,732 \\
Butir 31 & 0,467 & \\
Butir 55 & 0,381 & \\
Butir 79 & 0,477 & \\
Butir 103 & 0,601 & \\
Butir 127 & 0,522 & \\
\hline
\end{tabular}

Dengan demikian, peneliti menyimpulkan bahwa pengukuran character strength pada ranah ketekunan tergolong reliabel dengan butir-butir yang baik. Selanjutnya, pada ranah kedelapan, yakni kejujuran atau honesty, peneliti menguji enam butir yang menggambarkan character strength ranah kejujuran. Hasil uji korelasi menunjukkan bahwa skala sudah 
tergolong reliabel, dengan skor $\alpha=0,620$ dengan rentang skor $r_{\text {it }}$ sebesar 0,302 hingga 0,509 . Gambaran lebih mendetail tercatat dalam tabel 8.

Tabel 8. Hasil Uji reliabilitas dan Analisis Butir Ranah Kejujuran

\begin{tabular}{lcc}
\hline No. Butir & \multicolumn{2}{c}{ Hasil Pengujian } \\
\cline { 2 - 3 } & $\mathrm{r}_{\text {it }}$ & $\alpha$ \\
\hline Butir 8 & 0,400 & 0,620 \\
Butir 32 & 0,509 & \\
Butir 56 & 0,310 & \\
Butir 80 & 0,306 & \\
Butir 104 & 0,313 & \\
Butir 128 & 0,302 & \\
\hline
\end{tabular}

Berdasarkan hasil pengukuran ini, maka peneliti menyimpulkan bahwa pengukuran pada ranah kejujuran tergolong reliabel dengan butir-butir yang dapat mengukur dengan baik.

Pengujian pada ranah semangat atau zest pada mulanya menunjukkan skor $\alpha=706$. Setelah peneliti membuang satu butir, terjadi kenaikan skor Cronbach's Alpha menjadi $\alpha=$ 0,724. Sedangkan hasil pengujian melalui korelasi butir-total yang dikoreksi menunjukkan rentang skor $r_{i t}=0,405-0,582$. Adapun tabel 9 mencantumkan angka-angkanya dengan mendetail.

Tabel 9. Hasil Uji reliabilitas dan Analisis Butir Ranah Semangat

\begin{tabular}{lcccc}
\hline \multirow{2}{*}{ No. Butir } & \multicolumn{2}{c}{ Hasil Awal } & \multicolumn{2}{c}{ Hasil Akhir } \\
\cline { 2 - 5 } & $\mathrm{r}_{\text {it }}$ & $\alpha$ & $\mathrm{r}_{\text {it }}$ & $\alpha$ \\
\hline Butir 9 & 0,303 & 0,706 & (butir & 0,724 \\
& & & dibuang) & \\
Butir 33 & 0,511 & & 0,521 & \\
Butir 57 & 0,547 & & 0,582 & \\
Butir 81 & 0,464 & & 0,502 & \\
Butir 105 & 0,452 & & 0,405 & \\
Butir 129 & 0,427 & & 0,441 & \\
\hline
\end{tabular}

Dari hasil tersebut, peneliti menyimpulkan bahwa pengukuran character strength pada ranah semangat tergolong reliabel.

Selanjutnya adalah pengujian pada ranah kesepuluh, yakni cinta atau love. Mula-mula hasil uji reliabilitas menunjukkan reliabilitas yang kurang memuaskan, yakni $\alpha=0,378$. Namun 
setelah terdapat beberapa butir yang dibuang, reliabilitas meningkat menjadi 0,622. Detail hasil pengujian tercatat pada tabel 10 .

Tabel 10. Hasil Uji reliabilitas dan Analisis Butir Ranah Cinta

\begin{tabular}{lcccc}
\hline \multirow{2}{*}{ No. Butir } & \multicolumn{2}{c}{ Hasil Awal } & \multicolumn{2}{c}{ Hasil Akhir } \\
\cline { 2 - 5 } & $\mathrm{r}_{\text {it }}$ & $\alpha$ & $\mathrm{r}_{\text {it }}$ & $\alpha$ \\
\hline Butir 10 & 0,146 & 0,378 & $\begin{array}{c}\text { (butir } \\
\text { dibuang) }\end{array}$ & 0,622 \\
& & & (butir & \\
Butir 34 & 0,129 & & dibuang) & \\
& & & 0,478 & \\
Butir 58 & 0,441 & & 0,523 & \\
Butir 82 & 0,297 & & 0,334 & \\
Butir 106 & 0,330 & & (butir & \\
Butir 130 & $-0,137$ & & dibuang) \\
& & &
\end{tabular}

Berdasarkan hasil tersebut, maka dapat dianggap bahwa pengukuran pada ranah cinta tergolong cukup reliabel dengan butir-butir yang baik.

Selanjutnya adalah ranah kebaikan hati atau kindness. Hasil uji reliabilitas menunjukkan $\alpha=0,868$ dengan butir-butir yang tergolong baik, seperti yang terlampir dalam tabel 11.

Tabel 11. Hasil Uji reliabilitas dan Analisis Butir Ranah Kebaikan Hati

\begin{tabular}{lcc}
\hline \multirow{2}{*}{ No. Butir } & \multicolumn{2}{c}{ Hasil Pengujian } \\
\cline { 2 - 3 } & $\mathrm{r}_{\text {it }}$ & $\alpha$ \\
\hline Butir 11 & 0,350 & 0,868 \\
Butir 35 & 0,366 & \\
Butir 59 & 0,604 & \\
Butir 83 & 0,477 & \\
Butir 107 & 0,379 & \\
Butir 131 & 0,371 & \\
\hline
\end{tabular}

Dengan demikian, peneliti menyimpulkan bahwa pengukuran character strength pada ranah kebaikan hati tergolong reliabel dengan butir-butir yang baik.

Ranah keduabelas adalah ranah kecerdasan sosial atau social intelligence. Hasil uji reliabilitas pada awalnya menunjukkan skor Cronbach's Alpha yang jauh dari memuaskan, yakni $\alpha=-0,197$. Setelah membuang beberapa butir dengan daya diskriminasi butir yang 
kurang baik, terjadi peningkatan skor Cronbach's Alpha menjadi 0,649. Tabel 12 mendeskripsikan proses tersebut.

Tabel 12. Hasil Uji reliabilitas dan Analisis Butir Ranah Kecerdasan Sosial

\begin{tabular}{lcccc}
\hline \multirow{2}{*}{ No. Butir } & \multicolumn{2}{c}{ Hasil Awal } & \multicolumn{2}{c}{ Hasil Akhir } \\
& $\mathrm{r}_{\text {it }}$ & $\alpha$ & $\mathrm{r}_{\text {it }}$ & $\alpha$ \\
\hline Butir 12 & $-0,112$ & $-0,197$ & (butir dibuang) & 0,649 \\
Butir 36 & $-0,473$ & & (butir dibuang) & \\
Butir 60 & $-0,113$ & & (butir dibuang) & \\
Butir 84 & 0,222 & & 0,395 & \\
Butir 108 & 0,320 & & 0,504 & \\
Butir 132 & 0,091 & & 0,358 & \\
\hline
\end{tabular}

Dengan demikian, dapat disimpulkan bahwa pengukuran character strength pada ranah kecerdasan sosial tergolong reliabel dengan butir-butir yang berdaya diskriminasi baik.

Selanjutnya adalah ranah kerjasama atau teamwork. Pengukuran dengan 6 butir pernyataan diuji reliabilitasnya, menghasilkan skor Cronbach's Alpha sebesar $\alpha=0,539$. Setelah beberapa butir dibuang, skor Cronbach's Alpha meningkat menjadi $\alpha=603$, seperti yang tercantum dalam tabel 13 .

Tabel 13. Hasil Uji reliabilitas dan Analisis Butir Ranah Kerjasama

\begin{tabular}{lcccc}
\hline \multirow{2}{*}{ No. Butir } & \multicolumn{2}{c}{ Hasil Awal } & \multicolumn{2}{c}{ Hasil Akhir } \\
& $\mathrm{r}_{\text {it }}$ & $\alpha$ & $\mathrm{r}_{\text {it }}$ & $\alpha$ \\
\hline Butir 13 & 0,466 & 0,539 & 0,461 & 0,603 \\
Butir 37 & 0,527 & & 0,551 & \\
Butir 61 & 0,205 & & 0,223 & \\
Butir 85 & 0,135 & & 0,319 & \\
Butir 109 & 0,147 & & (butir dibuang) & \\
Butir 133 & 0,370 & & (butir dibuang) & \\
\hline
\end{tabular}

Dengan demikian, peneliti menyimpulkan bahwa pengukuran pada ranah kerjasama tergolong reliabel dengan butir-butir yang tergolong cukup baik untuk mengukur ranah kerjasama.

Ranah selanjutnya adalah keadilan atau fairness. Pengukuran sebanyak 6 butir menghasilkan skor Cronbach's Alpha sebesar $\alpha=0,722$. Keenam butir pun menunjukkan daya diskriminasi yang baik, terlihat dari skor korelasi butir total yang dikoreksi setiap butir berada di atas 0,3 ; seperti yang bisa dilihat pada tabel 14 . 


\section{Tabel 14. Hasil Uji reliabilitas dan Analisis Butir Ranah Keadilan}

\begin{tabular}{lcc}
\hline No. Butir & \multicolumn{2}{c}{ Hasil Pengujian } \\
\cline { 2 - 3 } & $\mathrm{r}_{\text {it }}$ & $\alpha$ \\
\hline Butir 14 & 0,303 & 0,722 \\
Butir 38 & 0,465 & \\
Butir 62 & 0,423 & \\
Butir 86 & 0,554 & \\
Butir 110 & 0,490 & \\
Butir 134 & 0,593 & \\
\hline
\end{tabular}

Peneliti menyimpulkan bahwa pengukuran character strength pada ranah keadilan sudah tergolong baik.

Peneliti kemudian menguji reliabilitas pengukuran pada ranah kepemimpinan atau leadership. Keenam butir yang digunakan untuk mengukur ranah kepemimpinan menunjukkan skor reliabilitas yang baik, yakni $\alpha=0,736$ dengan nilai korelasi butir total yang dikoreksi berada pada kisaran $r_{i t}=0,316-0,651$. Tabel 15 memuat informasi tersebut secara mendetail.

\section{Tabel 15. Hasil Uji reliabilitas dan Analisis Butir Ranah Kepemimpinan}

\begin{tabular}{lcc}
\hline No. Butir & \multicolumn{2}{c}{ Hasil Pengujian } \\
\cline { 2 - 3 } & $\mathrm{r}_{\text {it }}$ & $\alpha$ \\
\hline Butir 15 & 0,316 & 0,736 \\
Butir 39 & 0,598 & \\
Butir 63 & 0,651 & \\
Butir 87 & 0,340 & \\
Butir 111 & 0,594 & \\
Butir 135 & 0,343 & \\
\hline
\end{tabular}

Berdasarkan dari hasil tersebut, maka peneliti menyimpulkan bahwa pengukuran character strength pada ranah kepemimpinan sudah tergolong baik.

Ranah selanjutnya adalah ranah pemaafan atau forgiveness. Hasil uji reliabilitas menunjukkan skor Cronbach's Alpha sebesar $\alpha=0,544$. Setelah satu butir dibuang, terjadi peningkatan skor Cronbach's Alpha menjadi $\alpha=0,754$. 
Tabel 16. Hasil Uji reliabilitas dan Analisis Butir Ranah Pemaafan

\begin{tabular}{lcccc}
\hline \multirow{2}{*}{ No. Butir } & \multicolumn{2}{c}{ Hasil Awal } & \multicolumn{2}{c}{ Hasil Akhir } \\
& $\mathrm{r}_{\text {it }}$ & $\alpha$ & $\mathrm{r}_{\text {it }}$ & $\alpha$ \\
\hline Butir 16 & 0,517 & 0,544 & 0,530 & 0,754 \\
Butir 40 & 0,536 & & 0,622 & \\
Butir 64 & 0,660 & & 0,661 & \\
Butir 88 & 0,271 & & 0,390 & \\
Butir 112 & $-0,354$ & & (butir dibuang) & \\
Butir 136 & 0,401 & & 0,463 & \\
\hline
\end{tabular}

Peneliti menyimpulkan bahwa pengukuran pada ranah pemaafan sudah tergolong reliabel dengan lima butir pengukuran yang berdaya diskriminasi baik.

Selanjutnya adalah ranah kerendahan hati atau humility. Hasil uji reliabilitas mula-mula menunjukkan hasil yang kurang memuaskan, yakni $\alpha=0,504$. Peneliti kemudian membuang tiga butir pernyataan yang memiliki daya diskriminasi rendah. Setelah ketiga butir tersebut dibuang, reliabilitas meningkat menjadi $\alpha=0,604$.

Tabel 17. Hasil Uji reliabilitas dan Analisis Butir Ranah Kerendahan Hati

\begin{tabular}{lcccc}
\hline \multirow{2}{*}{ No. Butir } & \multicolumn{2}{c}{ Hasil Awal } & \multicolumn{2}{c}{ Hasil Akhir } \\
\cline { 2 - 5 } & $\mathrm{r}_{\text {it }}$ & $\alpha$ & $\mathrm{r}_{\text {it }}$ & $\alpha$ \\
\hline Butir 17 & 0,143 & 0,504 & (butir dibuang) & 0,604 \\
Butir 41 & 0,195 & & 0,454 & \\
Butir 65 & 0,148 & & (butir dibuang) & \\
Butir 89 & 0,468 & & 0,450 & \\
Butir 113 & 0,451 & & 0,0371 & \\
Butir 137 & 0,241 & & (butir dibuang) & \\
\hline
\end{tabular}

Berdasarkan temuan tersebut maka peneliti menyimpulkan bahwa pengukuran ranah kerendahan hati sudah cukup reliabel dengan butir-butir yang baik.

Selanjutnya adalah character strength pada ranah kehati-hatian (prudence). Pengukuran dengan melibatkan enam butir pernyataan digunakan untuk mengukur kehatihatian. Hasil uji reliabilitas menunjukkan skor Cronbach's Alpha yang masih cenderung memuaskan, yakni $\alpha=0,703$. 


\section{Tabel 18. Hasil Uji reliabilitas dan Analisis Butir Ranah Kehati-hatian}

\begin{tabular}{lcc}
\hline No. Butir & \multicolumn{2}{c}{ Hasil Pengujian } \\
\cline { 2 - 3 } & $\mathrm{r}_{\text {it }}$ & $\alpha$ \\
\hline Butir 18 & 0,417 & 0,703 \\
Butir 42 & 0,299 & \\
Butir 66 & 0,394 & \\
Butir 90 & 0,468 & \\
Butir 114 & 0,485 & \\
Butir 138 & 0,565 & \\
\hline
\end{tabular}

Meski masih terdapat butir yang memiliki nilai korelasi butir total di bawah 0,3 (butir nomor 42), namun peneliti masih menyertakannya untuk rancangan skala akhir dengan pertimbangan pernyataan pada butir nomor 42 masih menggambarkan kehati-hatian, dan butir tersebut hanya berada 0,001 di bawah standar.

Peneliti kemudian menguji butir-butir yang disusun untuk mengukur ranah regulasi diri atau self-regulation. Hasil pengujian reliabiltias pertama menunjukkan $\alpha=0,645$, dan terdapat satu butir yang menunjukkan skor korelasi butir total di bawah 0,03 (rit $=0,181)$. Setelah butir dibuang, terjadi peningkatan reliabilitas menjadi $\alpha=0,661$.

Tabel 19. Hasil Uji reliabilitas dan Analisis Butir Ranah Regulasi Diri

\begin{tabular}{lcccc}
\hline \multirow{2}{*}{ No. Butir } & \multicolumn{2}{c}{ Hasil Awal } & \multicolumn{2}{c}{ Hasil Akhir } \\
\cline { 2 - 5 } & $\mathrm{r}_{\text {it }}$ & $\mathrm{A}$ & $\mathrm{r}_{\text {it }}$ & $\alpha$ \\
\hline Butir 19 & 0,416 & 0,645 & 0,446 & 0,661 \\
Butir 43 & 0,446 & & 0,485 & \\
Butir 67 & 0,181 & & (butir dibuang) & \\
Butir 91 & 0,400 & & 0,331 & \\
Butir 115 & 0,391 & & 0,395 & \\
Butir 139 & 0,410 & & 0,427 & \\
\hline
\end{tabular}

Peneliti menyimpulkan bahwa kelima butir tersebut dapat mengukur ranah regulasi diri dengan cukup reliabel. Selanjutnya adalah pengujian reliabilitas untuk ranah apresiasi terhadap seni dan keindahan (appreciation of arts and beauties). Peneliti menguji enam butir yang disusun untuk mengukur ranah tersebut. Hasil uji reliabilitas menunjukkan skor Cronbach's Alpha 
sebesar $\alpha=0,832$. Tidak ada butir yang dibuang karena kesemua butirnya menunjukkan skor korelasi butir total di atas 0,03 .

Tabel 20. Hasil Uji reliabilitas dan Analisis Butir Ranah Apresiasi

\begin{tabular}{lcc}
\hline No. Butir & \multicolumn{2}{c}{ Hasil Pengujian } \\
\cline { 2 - 3 } & $\mathrm{r}_{\text {it }}$ & $\alpha$ \\
\hline Butir 20 & 0,688 & 0,832 \\
Butir 44 & 0,686 & \\
Butir 68 & 0,595 & \\
Butir 92 & 0,524 & \\
Butir 116 & 0,666 & \\
Butir 140 & 0,494 & \\
\hline
\end{tabular}

Dengan demikian, keenam butir yang disusun untuk mengukur ranah apresiasi sudah dapat digunakan.

Ranah selanjutnya yang diuji adalah ranah kebersyukuran atau gratitude. Hasil uji reliabilitas menunjukkan reliabilitas yang sebenarnya tergolong masih bisa diterima, yakni $\alpha=$ 583. Namun terdapat tiga butir yang memiliki skor korelasi butir total di bawah 0,3 ; sehingga peneliti membuang ketiga butir tersebut dan mendapatkan peningkatan reliabilitas menjadi $\alpha=$ 772. Deskripsi lengkap terdapat pada tabel 21.

\section{Tabel 21. Hasil Uji reliabilitas dan Analisis Butir Ranah Kebersyukuran}

\begin{tabular}{lcccc}
\hline \multirow{2}{*}{ No. Butir } & \multicolumn{2}{c}{ Hasil Awal } & \multicolumn{2}{c}{ Hasil Akhir } \\
& $\mathrm{r}_{\text {it }}$ & $\mathrm{A}$ & $\mathrm{r}_{\text {it }}$ & $\alpha$ \\
\hline Butir 21 & 0,560 & 0,583 & 0,611 & 0,779 \\
Butir 45 & 0,093 & & (butir dibuang) & \\
Butir 69 & 0,209 & & (butir dibuang) & \\
Butir 93 & 0,125 & & (butir dibuang) & \\
Butir 117 & 0,527 & & 0,592 & \\
Butir 141 & 0,561 & & 0,655 & \\
\hline
\end{tabular}

Peneliti kemudian menyimpulkan bahwa pengukuran ranah kebersyukuran masih tergolong reliabel, dengan menggunakan tiga butir pengukuran.

Selanjutnya peneliti menguji reliabilitas pada ranah harapan atau hope. Hasil uji reliabilitas menunjukkan skor reliabilitas sebesar $\alpha=0,768$. Tidak ada butir yang dibuang pada ranah ini. 


\section{Tabel 22. Hasil Uji reliabilitas dan Analisis Butir Ranah Harapan}

\begin{tabular}{lcc}
\hline No. Butir & \multicolumn{2}{c}{ Hasil Pengujian } \\
\cline { 2 - 3 } & $\mathrm{r}_{\mathrm{it}}$ & $\alpha$ \\
\hline Butir 22 & 0,441 & 0,768 \\
Butir 46 & 0,584 & \\
Butir 70 & 0,454 & \\
Butir 94 & 0,595 & \\
Butir 118 & 0,614 & \\
Butir 142 & 0,477 & \\
\hline
\end{tabular}

Peneliti menyimpulkan bahwa pengukuran pada ranah harapan tergolong reliabel dan butirbutir dapat digunakan.

Peneliti kemudian menguji reliabilitas ranah ke-23, yakni ranah humor. Peneliti menguji keenam butir yang disusun untuk mengukur ranah tersebut. Hasil uji reliabilitas menunjukkan skor reliabilitas yang tergolong cukup memuaskan, yakni $\alpha=695$. Namun terdapat dua butir yang harus dibuang karena memiliki daya diskriminasi yang kurang memuaskan. Setelah kedua butir tersebut dibuang, skor Cronbach's Alpha meningkat menjadi $\alpha=734$

Tabel 23. Hasil Uji reliabilitas dan Analisis Butir Ranah Humor

\begin{tabular}{lcccc}
\hline \multirow{2}{*}{ No. Butir } & \multicolumn{2}{c}{ Hasil Awal } & \multicolumn{2}{c}{ Hasil Akhir } \\
& $\mathrm{r}_{\text {it }}$ & $\mathrm{A}$ & $\mathrm{r}_{\text {it }}$ & $\alpha$ \\
\hline Butir 23 & 0,292 & 0,695 & (butir dibuang) & 0,734 \\
Butir 47 & 0,271 & & (butir dibuang) & \\
Butir 71 & 0,588 & & 0,713 & \\
Butir 95 & 0,639 & & 0,707 & \\
Butir 119 & 0,395 & & 0,302 & \\
Butir 143 & 0,425 & & 0,444 & \\
\hline
\end{tabular}

Berdasarkan temuan-temuan di atas, maka peneliti menyimpulkan bahwa butir-butir pada ranah humor dapat mengukur ranah humor dengan baik, meski menyisakan empat butir.

Ranah terakhir adalah ranah spiritualitas atau spirituality. Hasil pengujian reliabilitas menunjukkan reliabilitas sebesar $\alpha=0,698$. Terdapat satu butir yang harus dibuang karena memiliki daya diskriminasi yang sangat tidak memuaskan. Setelah butir itu dibuang, terjadi peningkatan reliabilitas menjadi $\alpha=0,771$. 
Tabel 24. Hasil Uji reliabilitas dan Analisis Butir Ranah Spiritualitas

\begin{tabular}{lcccc}
\hline \multirow{2}{*}{ No. Butir } & \multicolumn{2}{c}{ Hasil Awal } & \multicolumn{2}{c}{ Hasil Akhir } \\
& $\mathrm{r}_{\text {it }}$ & $\mathrm{A}$ & $\mathrm{r}_{\text {it }}$ & $\alpha$ \\
\hline Butir 24 & 0,586 & 0,698 & 0,593 & 0,771 \\
Butir 48 & 0,631 & & 0,623 & \\
Butir 72 & 0,007 & & (butir dibuang) & \\
Butir 96 & 0,454 & & 0,477 & \\
Butir 120 & 0,534 & & 0,552 & \\
Butir 144 & 0,409 & & 0,480 & \\
\hline
\end{tabular}

Dengan demikian, pengukuran pada ranah spiritualitas juga disimpulkan reliabel.

Setelah melalui proses pengujian reliabilitas dan analisis butir, maka peneliti menyimpulkan seluruh ranah dalam alat ukur ini tergolong reliabel, dengan rentang 0,520 0,858. Pada awalnya, alat ukur ini terdiri dari 144 butir, namun setelah butir-butir yang berdaya diskriminasi rendah dibuang, tersisa 120 butir yang dapat digunakan untuk mengukur character strengths. Tabel 25 memuat simpulan ini dengan lebih terstruktur. 
Tabel 25. Hasil Akhir Alat Ukur

\begin{tabular}{|c|c|c|c|c|}
\hline \multirow{2}{*}{ No. } & \multirow{2}{*}{ Ranah } & \multicolumn{2}{|c|}{ Jumlah Butir } & \multirow{2}{*}{ Reliabilitas } \\
\hline & & Rancangan & Akhir & \\
\hline 1. & Kreativitas (creativity) & 6 & 5 & 0,779 \\
\hline 2. & Keingintahuan (curiosity) & 6 & 6 & 0,821 \\
\hline 3. & Penilaian (judgment) & 6 & 4 & 0,592 \\
\hline 4. & $\begin{array}{l}\text { Kecintaan terhadap belajar } \\
\text { (love of learning) }\end{array}$ & 6 & 5 & 0,776 \\
\hline 5. & Perspektif (perspective) & 6 & 4 & 0,520 \\
\hline 6. & Keberanian (bravery) & 6 & 5 & 0,637 \\
\hline 7. & Ketekunan (perseverance) & 6 & 6 & 0,732 \\
\hline 8. & Kejujuran (honesty) & 6 & 6 & 0,620 \\
\hline 9. & Semangat (zest) & 6 & 5 & 0,724 \\
\hline 10. & Cinta (love) & 6 & 3 & 0,622 \\
\hline 11. & Kebaikan Hati (kindness) & 6 & 6 & 0,868 \\
\hline 12. & $\begin{array}{l}\text { Kecerdasan Sosial } \\
\text { (social intelligence) }\end{array}$ & 6 & 3 & 0,649 \\
\hline 13. & Kerjasama (teamwork) & 6 & 4 & 0,603 \\
\hline 14. & Keadilan (fairness) & 6 & 6 & 0,722 \\
\hline 15. & Kepemimpinan (leadership) & 6 & 6 & 0,736 \\
\hline 16. & Pemaafan (forgiveness) & 6 & 5 & 0,754 \\
\hline 17. & Kerendahan Hati (humility) & 6 & 3 & 0,604 \\
\hline 18. & Kehati-hatian (prudence) & 6 & 6 & 0,703 \\
\hline 19. & Regulasi Diri (self-regulation) & 6 & 5 & 0,661 \\
\hline 20. & Apresiasi (appreciation) & 6 & 6 & 0,832 \\
\hline 21. & Kebersyukuran (gratitude) & 6 & 6 & 0,779 \\
\hline 22. & Harapan (hope) & 6 & 6 & 0,768 \\
\hline 23. & Humor & 6 & 4 & 0,734 \\
\hline 24. & Spiritualitas (spirituality) & 6 & 5 & 0,771 \\
\hline & Jumlah & 144 & 120 & \\
\hline
\end{tabular}

\section{DISKUSI}

Berdasarkan pengujian reliabiltias dan analisis butir, skala ini sudah tergolong dapat digunakan. Namun ada beberapa catatan yang masih perlu diperhatikan, yakni terdapat dua ranah yang memiliki nilai Cronbach's Alpha sekitar 0,5. Beberapa pakar mensyaratkan bahwa skala yang baik adalah skala yang memiliki nilai Cronbach's Alpha di atas 0,7 (Cortina, 1993). Jika menggunakan standar ini, maka terdapat beberapa ranah yang reliabilitasnya dipertanyakan. Namun, Taber (2018) menyatakan bahwa nilai Cronbach's Alpha pada kisaran 0,5 sudah tergolong memuaskan. Peneliti menilai bahwa beberapa ranah yang bernilai 
Cronbach's Alpha sekitar 0,50 hingga 0,69 masih dapat diterima dengan pertimbangan jumlah butir pada masing-masing ranah hanya terdiri atas 6 buah, sehingga memang sulit untuk mendapatkan nilai Cronbach's Alpha yang tinggi. Jumlah butir yang sedikit sangat memengaruhi nilai Cronbach's Alpha, karena perhitungan nilai tersebut juga bergantung pada jumlah butir yang tersedia. Karena itu, kedua ranah yang memiliki skor Cronbach's Alpha pada kisaran 0,5 masih dapat diterima.

\section{KESIMPULAN DAN SARAN}

Hasil penelitian ini menunjukkan bahwa alat ukur character strengths yang sudah disusun dapat mengukur konstruk dengan properti pengukuran yang baik. Masing-masing ranah pengukuran menunjukkan reliabilitas yang dapat diterima, dengan butir yang disusun berdasarkan teori dan melalui proses analisis secara statistik. Alat ukur ini nantinya dapat digunakan untuk penelitian-penelitian character strengths dalam konteks Indonesia.

Meski demikian, peneliti masih menemukan beberapa hal yang masih bisa dilakukan untuk mengembangkan alat ukur ini. Pertama adalah dalam hal jumlah partisipan penelitian, di mana hasil pengujian statistik akan lebih adekuat lagi bila jumlah partisipan yang terlibat bisa lebih banyak. Kedua adalah terkait validitas konstruk yang dapat dilakukan melalui analisis faktor konfirmatori. Kedua hal ini dapat menjadi pertimbangan untuk penelitian selanjutnya.

\section{DAFTAR PUSTAKA}

Bakker, A.B., Hetlan, J., Olsen, O.K., \& Espevik, R. (2018). Daily strengths use and employee well-being: The moderating role of personality. Journal of Occupational and Organizational Psychology, 92(1), 144-168. doi: 10.1111/joop.12243.

Cortina, J.M. (1993). What is coefficient alpha? An examination of theory and applications. Journal of Applied Psychology, 78(1), 98-104.

Douglass, R.P., \& Duffy, R.D. (2015). Strengths use and life satisfaction: a moderated mediation approach. Journal of Happiness Studies, 16(3), pp.619-632. doi: 10.1007/s10902-014-9525-4

Gander, F., Hofmann, J., Proyer, R.T., \& Ruch, W. (2018). Character strengths: Stability, change, and relationships with well-being changes. Applied Research in Quality of Life. Advanced online publication. https://doi.org/10.1007/s11482-018-9690-4

Duckworth, A. (2016). Grit: The power of passion and perseverance. NY: HarperCollins. 
Harzer, C. (2016). The eudaimonics of human strengths: the relations between character strengths and well-being. Dalam J. Vitterso (ed.), Handbook of Eudaimonic Well-Being (pp.307-322). Switzerland: Springer International Publishing. doi: 10.1007/978-3-31942445-3 20

Heintz, S., \& Ruch, W. (2019). Character strengths and job satisfaction: Differential relationships across occupational groups and adulthood. Applied Research in Quality of Life. Advanced online publication. https://doi.org/10.1007/s11482-018-9691-3

Huber, A., Strecker, C., Hausler, M., Kachel, T., Hoge, T., \& Hofer, S. (2019). Possession and applicability of signature character strengths: What is essential for well-being, work engagement, and burnout? Applied Research in Quality of Life. Advanced online publication. https://doi.org/10.1007/s11482-018-9699-8

Lavy, S., \& Littman-Ovadia, H. (2017). My better self: Using strengths at work and work productivity, organizational citizenship behavior, and satisfaction. Journal of Career Development, 44(2), 1-15.

Martinez-Marti, M.L., \& Ruch, W. (2016). Character strengths predict resilience over and above positive affect, self-efficacy, optimism, social support, self-esteem, and life satisfaction. The Journal of Positive Psychology, 12(2), 110-119.

Maryana, H. (2015). Pengaruh character strengths dan gender terhadap stres akademik mahasiswa UIN Jakarta yang kuliah sambil bekerja (Skripsi tidak dipublikasikan). UIN Syarif Hidayatullah, Jakarta.

Multahada, E. (2016). Peran kekuatan karakter terhadap resiliensi perawat. Jurnal Ilmu Ekonomi dan Sosial, 5(3), 275-279.

Neff, K. (2011). Self-compassion: The proven power of being kind to yourself. NY: William Morrow.

Park, N., \& Peterson, C. (2009). Character strengths: research and practice. Journal of College \& Character, 10(4), 1-10.

Peterson, C., \& Seligman, M.E.P. (2004). Character strengths and virtues. Oxford: Oxford University Press.

Peterson, C. (2006). A primer in positive psychology. Oxford: Oxford University Press.

Seligman, A. (2002). Authentic happiness. Using the new positive psychology to realize your potential for lasting fulfillment. NY: The Free Press.

Taber, K.S. (2018). The use of Cronbach's alpha when developing and reporting research instruments in science education. Research in Science Education, 48, 1273-1296.

Wagner, L., Gander, F., Proyer, R.T., \& Ruch, W. (2019). Character strengths and PERMA: Investigating the relationships of character strengths with a multidimensional framework of well-being. Applied Research in Quality of Life, January 2019. doi: $10.1007 / \mathrm{s} 11482-018-9695-\mathrm{z}$ 
